\title{
Clinical Reasoning: Complex ataxia
}

\section{Unpicking the threads}

Tarig Abkur, MRCP(UK), Kayal Vijayakumar, MRCPCH, Amanda J. Churchill, PhD, FRCOphth, and James Stevens, MA, PhD, FRCP, DTM\&H

Neurology ${ }^{\circledR}$ 2020;95:136-141. doi:10.1212/WNL.0000000000009886

\section{Section 1}

A 20-year-old right-handed woman was seen in neurology clinic for evaluation of progressive unsteadiness. Her symptoms began at age 10, with clumsiness and frequent falls. Her toes gradually became clawed, requiring bilateral cavovarus foot corrective surgery. She reported no sensory symptoms or visual or sphincter disturbance.

The patient's older brother had similar symptoms, as did both of her twin sisters, at age 12 . There was no similar history in her parents' families. Her parents and her mother's parents are first cousins (figure 1).

On examination, the patient had a full range of eye movements, but pursuit movements were broken. Saccadic eye movements were normal and there was no nystagmus evident.

Figure 1 Family pedigree chart

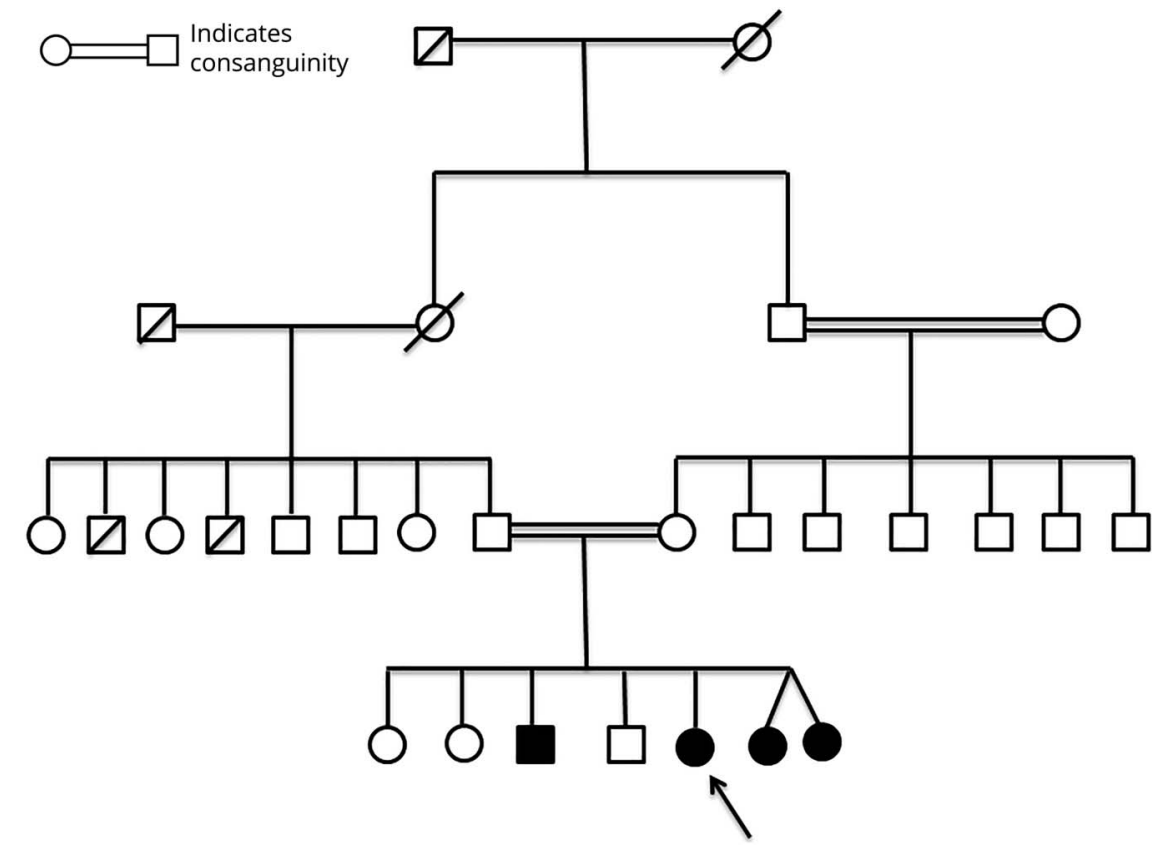

Circles indicate female family members, and squares male family members; slashes indicate that the family member is deceased. Family members with neurological involvement are indicated by solid symbols, and those without by open symbols.

\section{Correspondence}

Tarig Abkur

tarig.abkur@nbt.nhs.uk 
Funduscopic examination was normal. Her speech was unremarkable. Tone, motor function, and sensory examination were normal in the upper limbs. Muscle stretch reflexes in the upper extremities were present with reinforcement.

Finger-nose testing revealed bilateral past pointing and intention tremor. Examination of the legs revealed hammertoes and scars from foot surgery. Tone was normal. The patient had bilateral weakness of hip flexion (Medical Research Council 4/5), hip extension $(4+/ 5)$, foot inversion $(4+/ 5)$, eversion $(4+/ 5)$, and extensor hallucis longus (4/5). Knee jerks were present with reinforcement, but ankle jerks were absent. Plantars were upgoing.

Vibration sense was diminished to the ankles. Joint position sense was normal. Pinprick sensation was altered over the patient's feet although light touch sensation was normal. She had a slightly broad-based gait but could ambulate without aid. A Romberg test was negative.

\section{Questions for consideration:}

1. How would you describe the clinical picture?

2. What is your differential diagnosis?

GO TO SECTION 2 


\section{Section 2}

The clinical picture is primarily of cerebellar ataxia. When investigating ataxia, 4 points are particularly relevant: the age at onset, the speed of progression, the family history, and the medical background. Clinicians should look for signs that indicate extracerebellar system involvement, to narrow the differential diagnosis further (e.g., autonomic failure and parkinsonism in multiple system atrophy or ophthalmoplegia in mitochondrial disorders). In this case, leg weakness, absent ankle jerks, distally altered sensation, and upgoing plantars are relevant.

Causes of ataxia can be divided into genetic and acquired forms. A very slowly progressive ataxia over many years and the positive family history with 3 siblings affected points towards a genetic cause. The lack of clear vertical transmission from one generation to the next within this family is against a dominantly inherited condition. The consanguinity observed in this family favors recessive inheritance. ${ }^{1}$

Unlike our case, acquired causes of ataxia are more likely to have subacute or acute onset (e.g., cerebellar stroke or paraneoplastic cerebellar syndromes) and may be accompanied by lateralizing signs. ${ }^{2}$

In addition to ataxia, the absent ankle jerks, impaired vibration sense, and distal weakness point towards peripheral neuropathy. The presence of neuropathy, assuming a unifying cause, narrows the differential further.
Cerebellar ataxia with peripheral neuropathy can be a manifestation of several conditions including acquired causes such as chronic alcoholism, celiac disease, vitamin $\mathrm{B}_{12}$ and $\mathrm{E}$ deficiency, and paraneoplastic syndromes. Genetic causes can be further subclassified based on the predominant pattern of the associated neuropathy.

Neurophysiologic studies may therefore help in further subcategorizing ataxia syndromes. A predominant axonal neuropathy may accompany genetic ataxia syndromes including Friedreich ataxia, ataxia telangiectasia, ataxia with oculomotor apraxia, fragile $\mathrm{X}$ tremor ataxia syndrome, abetalipoproteinemia leukoencephalopathy with brainstem and spinal cord involvement and lactate elevation, mitochondrial disorders (e.g., sensory ataxic neuropathy, dysarthria, and ophthalmoparesis), cerebellar ataxia neuropathy, and bilateral vestibular areflexia syndrome and spinocerebellar ataxia (SCA) types 1, 2, 3,7,10, 12, 21, 23, 27 , and $36 .^{3}$

Conversely, a very limited number of genetic ataxia conditions (autosomal recessive spastic ataxia of Charlevoix-Saguenay [ARSACS]), cerebrotendinous xanthomatosis, and Refsum disease) may manifest with cerebellar ataxia with an associated slow nerve conduction velocity, suggesting a predominantly demyelinating neuropathy. ${ }^{3}$

\section{Question for consideration:}

1. How would you investigate this patient? 


\section{Section 3}

Initial blood tests were normal, including full blood count, urea and electrolytes, bone profile, liver function, angiotensinconverting enzyme, $\alpha$-fetoprotein, phytanic acid, copper, zinc, vitamins $\mathrm{A}$ and $\mathrm{E}$, antitissue transglutaminase, and white cell lysosomal enzymes. Comprehensive autoimmune screening was negative for antinuclear antibodies, antineutrophil cytoplasmic antibodies, rheumatoid factor, antiphospholipid antibodies, and cryoglobulins. Serologic tests for syphilis, hepatitis B and C, and HIV were negative.
Neurophysiologic studies were consistent with a predominantly demyelinating sensorimotor neuropathy. The patient's condition continued to deteriorate very slowly, and she was transitioned to the adult neurology service for continued care.

Questions for consideration:

1. Would you perform any other tests?

2. What is the most likely diagnosis?

GO TO SECTION 4 


\section{Section 4}

The patient had genetic tests for Friedreich ataxia and for the most common repeat expansion (SCAs 1, 2, 3, 6, 7, and 17), which were negative. Because brain imaging with MRI is crucial in evaluating patients with ataxia, our patient underwent MRI of the brain, which showed superior vermian atrophy, thinning of the corpus callosum, T2 hyperintense signs around the thalami, bulky pons, and linear $\mathrm{T} 2$ pontine hypointense abnormalities (figure 2).

In view of the consanguinity, the clinical phenotype of cerebellar ataxia with an associated demyelinating neuropathy and pyramidal signs, and the characteristic MRI findings of bilateral T2 hypointense pontine linear abnormalities, a clinical diagnosis of ARSACS was made. Genetic testing in one sibling demonstrated a homozygous mutation c.407 409 del CTC in the sacsin gene (SACS) resulting in the deletion of glutamine and threonine residues and the insertion of lysine.

\section{Discussion}

The presence of pontine linear hypointensities on MRI appears to be a sensitive marker of ARSACS. ${ }^{4}$ Retinal nerve fiber layer thickening is a useful clinical clue to the diagnosis of
ARSACS, when found. ${ }^{5}$ This may be seen on funduscopic examination and optical coherence tomography can be used to characterize it further (figure 2).

MRI may show key diagnostic clues in cases of ataxia (e.g., hot cross bun sign in patients with multiple system atrophy, middle cerebellar peduncle sign in patients with fragile $\mathrm{X}$-associated tremor/ataxia syndrome, basal ganglia hyperintensity with cortical diffusion restriction in prion disease, cerebellar and brainstem rim of hypointensity in superficial siderosis). ${ }^{6}$

In genetic ataxia, identifying the mode of inheritance may guide genetic testing. Genetic causes of ataxia should also be considered in apparent sporadic cases as these may arise due to de novo mutations, variable penetrance of mutations, or misattributed paternity. In simple terms, genetic ataxias presenting before the age of 20 are more commonly recessive and those presenting over the age of 25 , dominant. X-linked forms are exceedingly rare.

As outlined above, accurate phenotyping of any case of ataxia is essential and, despite its age, the approach outlined by Harding ${ }^{8}$ in 1984 remains valid. For example, the relatively "pure" cerebellar ataxia of SCA6 contrasts with the more complex SCA7, in which neurologic signs other than ataxia

Figure $2 \mathrm{MRI}$ of the brain and retinal photographs and optic coherence tomography of the patient's sister's left eye
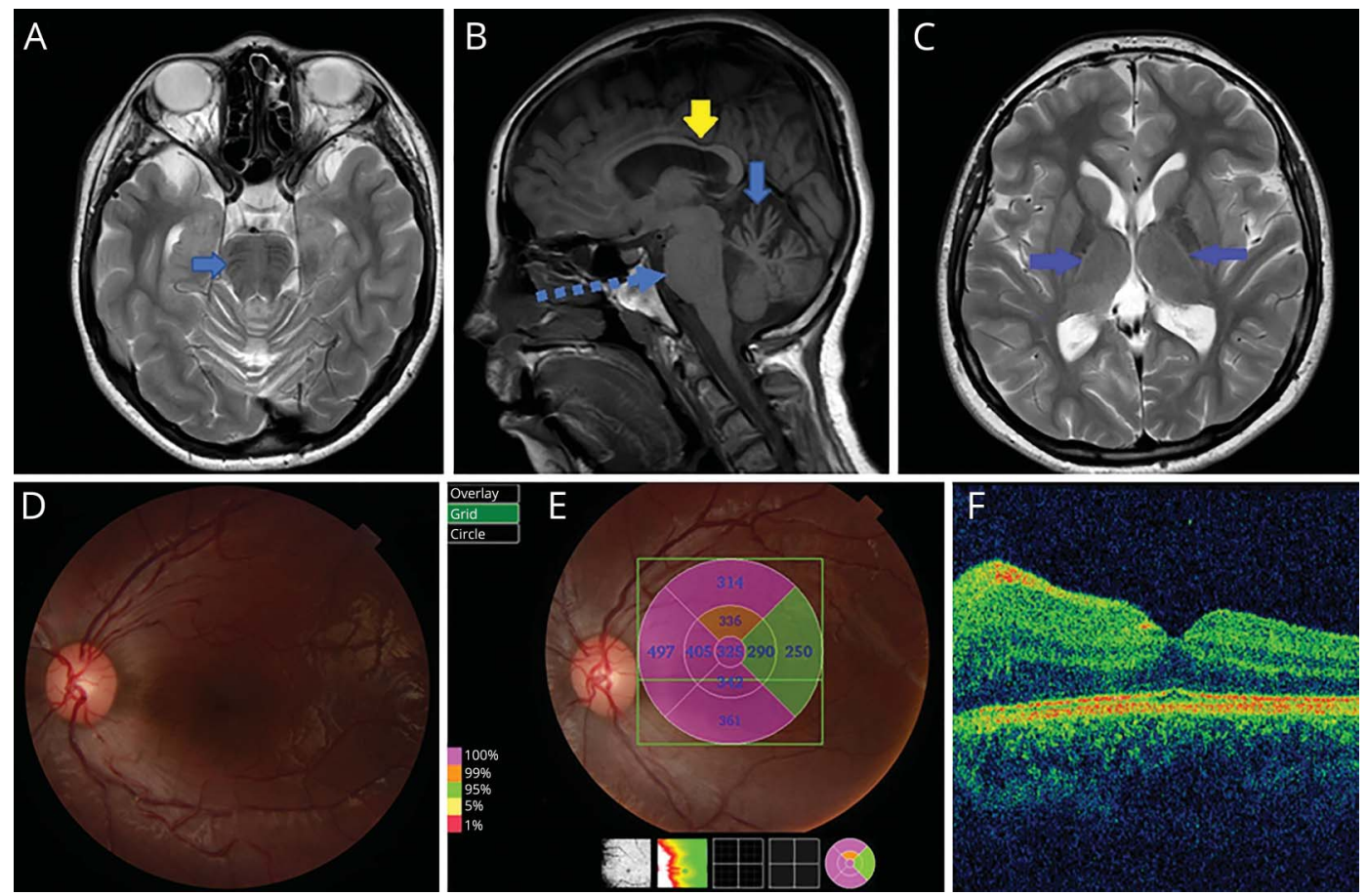

(A) Axial T2 sequence shows bilateral pontine linear hypointense lesion (arrow). (B) Sagittal T1 sequence shows thinning of the corpus callosum (yellow arrow), superior vermian atrophy (blue arrow), and bulky pons (interrupted arrow). (C) Axial T2 shows T2 hyperintensities around the thalami (arrows). (D) Fundus photograph from the patient's sister's left eye shows retinal nerve fiber layer thickening. (E) Fundus photograph of the patient's sister's left eye with grid overlay to show the thickness of the retina in micrometers. The pink areas illustrate where the retina is significantly thickened. (F) Ocular coherence tomography image of same left eye showing normal foveal pit (center of image) and thickened retina to the left of center, corresponding to the pink area on the fundus photograph above. 
may be seen, such as progressive visual loss due to macular dystrophy.

Given the considerable clinical overlap between genetic causes of ataxia, a panel-based approach to genetic testing is often preferred. However, more targeted testing (i.e., for a single gene) can be considered if a patient originates from a place where a specific type of ataxia is prevalent (e.g., SCA2 in Cuba). The presence of a key clinical feature (such as visual loss due to retinal degeneration in SCA7) may also justify testing for a single gene rather than a panel. ${ }^{9}$

In the case of dominantly inherited ataxias, we commonly employ a panel-based approach. Our initial panel tests include those for triplet repeat expansions (SCA1, 2, 3, 6, 7, and 17) given their high prevalence, with consideration of nextgeneration sequencing (NGS) if these are negative. However, it is important to appreciate that current NGS techniques may not detect untranslated repeats.

In the case of recessively inherited disorders, we endeavor to identify a laboratory biomarker (e.g., low vitamin $\mathrm{E}$ in ataxia with isolated vitamin $\mathrm{E}$ deficiency), or a signature clinical/ radiologic feature (e.g., tendon xanthomas in cerebrotendinous xanthomatosis, telangiectasia in ataxia telangiectasia, or $\mathrm{T} 2$ hypointense pontine linear abnormalities in ARSACS). Such features may help narrow the differential diagnosis.

The commonest cause of recessively inherited ataxia in our patient population is Friedreich ataxia. In addition, a triplet expansion in the replication factor $\mathrm{C}$ subunit 1 (RFC1) gene has recently been found in about $22 \%$ of patients with apparent sporadic late-onset ataxia. ${ }^{10}$ Some genes more commonly linked to other conditions (e.g., SPG7, traditionally linked to hereditary spastic paraplegia) have also been shown to manifest with ataxia when mutated. However, when testing for Friedreich ataxia is negative, and where the initial workup identifies no other laboratory/radiologic marker, NGS may be informative.

In more complex ataxias, consideration should be given to which clinical feature is key; e.g., in Marinesco-Sjogren syndrome, a search of genes causing premature cataract formation may be a quicker route to finding a mutation in SIL 1 than a search for genetic causes of ataxia. Understanding the technical limitations of genetic testing is essential. Appropriate liaison with clinical geneticists has, in our experience, added greatly to this process. Referral to a specialist clinic may be of value for patients in whom an initial screen has not identified a certain cause.

\section{Study funding}

No funding was sought or obtained for this study.

\section{Disclosure}

The authors report no disclosures relevant to the manuscript. Go to Neurology.org/N for full disclosures.

\begin{tabular}{|c|c|c|}
\hline Name & Location & Contribution \\
\hline $\begin{array}{l}\text { Tarig Abkur, } \\
\text { MRCP(UK) }\end{array}$ & $\begin{array}{l}\text { Department of Neurology, } \\
\text { Southmead Hospital }\end{array}$ & $\begin{array}{l}\text { Drafted the article and } \\
\text { reviewed the literature }\end{array}$ \\
\hline $\begin{array}{l}\text { Kayal } \\
\text { Vijayakumar } \\
\text { MRCPCH }\end{array}$ & $\begin{array}{l}\text { Department of Paediatric } \\
\text { Neurology, University } \\
\text { Hospital Bristol NHS } \\
\text { Foundation Trust; School } \\
\text { of Medicine, University of } \\
\text { Bristol }\end{array}$ & $\begin{array}{l}\text { Helped with } \\
\text { interpretation of the } \\
\text { images provided, } \\
\text { literature review }\end{array}$ \\
\hline $\begin{array}{l}\text { Amanda J } \\
\text { Churchill, } \\
\text { PhD, } \\
\text { FRCOphth }\end{array}$ & $\begin{array}{l}\text { School of Medicine, } \\
\text { University of Bristol; } \\
\text { Department of } \\
\text { Ophthalmology, Bristol Eye } \\
\text { Hospital }\end{array}$ & $\begin{array}{l}\text { Helped with } \\
\text { interpretation of the } \\
\text { images provided, } \\
\text { literature review }\end{array}$ \\
\hline $\begin{array}{l}\text { James } \\
\text { Stevens, MA, } \\
\text { PhD, FRCP, } \\
\text { DTM\&H }\end{array}$ & $\begin{array}{l}\text { Department of Neurology, } \\
\text { Southmead Hospital; } \\
\text { School of Medicine, } \\
\text { University of Bristol }\end{array}$ & $\begin{array}{l}\text { Acted as a senior author, } \\
\text { reviewed the manuscript } \\
\text { for important intellectual } \\
\text { content }\end{array}$ \\
\hline
\end{tabular}

\section{References}

1. Hamamy H. Consanguineous marriages preconception consultation in primary health care settings. J Community Genet 2012;3:185-192.

2. Judith van Gaalen J, van de Warrenburg BPC. A practical approach to late-onset cerebellar ataxia. Pract Neurol 2012;12:14-24.

3. Rossor AM, Carr AS, Devine H, et al. Peripheral neuropathy in complex inherited diseases: an approach to diagnosis. J Neurol Neurosurg Psychiatry 2017;88: $846-863$.

4. Martin MH, Bouchard JP, Sylvain M, St-Onge O, Truchon S. Autosomal recessive spastic ataxia of Charlevoix-Saguenay: a report of MR imaging in 5 patients. Am J Neuroradiol 2007;28:1606-1608.

5. Parkinson MH, Bartmann AP, Clayton LMS, et al.. Optical coherence tomography in autosomal recessive spastic ataxia of Charlevoix-Saguenay. Brain 2018;141:989-999.

6. de Silva RN, Vallortigara J, Greenfield J, et al. Diagnosis and management of progressive ataxia in adults practical. Neurology 2019;19:196-207.

7. Jarman PR, Wood NW. Genetics of movement disorders and ataxia. J Neurol Neurosurg Psychiatry 2002;73:ii22-ii26.

8. Harding AE. The Hereditary Ataxias and Related Disorders. London: Churchill Livingstone; 1984:266.

9. Klockgether T, Mariotti C, Paulson HL. Spinocerebellar ataxia. Nat Rev Dis Primers 2019;5:24.

10. Cortese A, Simone R, Sullivan R, et al. Biallelic expansion of an intronic repeat in $\mathrm{rfcl}$ is a common cause of late-onset ataxia. Nat Genet 2019;51:649-658. 


\section{Neurology}

Clinical Reasoning: Complex ataxia: Unpicking the threads

Tarig Abkur, Kayal Vijayakumar, Amanda J. Churchill, et al.

Neurology 2020;95;136-141 Published Online before print July 6, 2020

DOI 10.1212/WNL.0000000000009886

This information is current as of July 6, 2020

\section{Updated Information \&} Services

References

Subspecialty Collections

\section{Permissions \& Licensing}

Reprints including high resolution figures, can be found at: http://n.neurology.org/content/95/3/136.full

This article cites 9 articles, 2 of which you can access for free at: http://n.neurology.org/content/95/3/136.full\#ref-list-1

This article, along with others on similar topics, appears in the following collection(s):

All Clinical Neurology

http://n.neurology.org/cgi/collection/all_clinical_neurology

All Education

http://n.neurology.org/cgi/collection/all_education

Gait disorders/ataxia

http://n.neurology.org/cgi/collection/gait_disorders_ataxia

MRI

http://n.neurology.org/cgi/collection/mri

Peripheral neuropathy

http://n.neurology.org/cgi/collection/peripheral_neuropathy

Information about reproducing this article in parts (figures,tables) or in its entirety can be found online at:

http://www.neurology.org/about/about_the_journal\#permissions

Information about ordering reprints can be found online:

http://n.neurology.org/subscribers/advertise

Neurology ${ }^{\circledR}$ is the official journal of the American Academy of Neurology. Published continuously since 1951, it is now a weekly with 48 issues per year. Copyright (C 2020 American Academy of Neurology. All rights reserved. Print ISSN: 0028-3878. Online ISSN: 1526-632X.

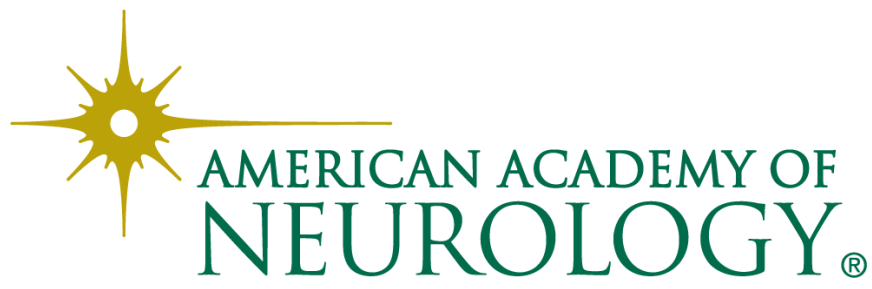

